\title{
ASPEK MORALITAS FILM CINDERELLA
}

\author{
Mu'thia Mubasyira \\ Program Pendidikan Bahasa Inggris \\ Fakultas Bahasa dan Seni \\ Universitas Indraprasta PGRI Jakarta \\ muthia.mubasyira@yahoo.com
}

\begin{abstract}
ABSTRAK
Karya sastra dapat berbentuk prosa, puisi ataupun film. Film sebagai salah satu bentuk dari karya sastra pun dapat dikatagorikan dalam bentuk fiksi dan non fiksi. Pada penelitian ini, penulis mengangkat film bertemakan ketulusan dan pengorbanan. Film yang diambil sebagai objek penelitian berjudul Cinderella. Adapun tujuan dari penelitian ini adalah untuk mengetahui dan menganalisis aspek-aspek moralitas yang terdapat dalam film ini. Penelitian ini diharapkan mampu menambah khazanah ilmu pengetahuan terutama sastra dan dapat menjadi referensi tambahan bagi peminatnya terutama peminat film.
\end{abstract}

Kata kunci: sastra, film, moralitas

\section{A. PENDAhUluAN}

Film menjadi media yang sangat berpengaruh, melebihi media-media yang lain. Oleh karena itu, penayangan film dengan audio dan visual bekerja membuat penontonnya tidak bosan dan lebih mudah mengingat. Film yang ditemukan pada akhir ke-19 dan terus berkembang hingga hari ini merupakan perkembangan lebih jauh dari teknologi fotografi.

Film dapat dijadikan alat yang memuat pesan-pesan atau amanat kepada penontonnya. Pesan atau amanat tersebut dapat berupa nasihat moral. Moral adalah sifat dasar yang diajarkan di sekolah, di rumah, maupun di lingkungan. Moral adalah sikap keabsolutan dalam kehidupan bermasyarakat secara utuh. Moral adalah perbuatan atau tingkah laku dan ucapan seseorang dalam berinteraksi dengan manusia lainnya. Moral merupakan produk dari budaya dan agama. Moral juga dapat diartikan sebagai sikap, perilaku, tindakan, kelakuan yang dilakukan seseorang pada saat mencoba melakukan sesuatu berdasarkan pengalaman, tafsiran, suara hati serta nasihat.

Moralitas merupakan aspek kepribadian yang perlu seseorang dalam kaitannya dengan kehidupan sosial secara harmonis, adil, dan seimbang. Perilaku moral diperlukan demi 
terwujudnya kehidupan yang damai penuh keteraturan, ketertiban, dan keharmonisan. Moral dalam kehidupan manusia memiliki kedudukan yang amat penting. Nilai-nilai moral sangat diperlukan bagi manusia, baik kapasitasnya sebagai pribadi maupun sebagai anggota suatu kelompok peradaban suatu bangsa yang dapat dinilai melalui karakter moral masyarakatnya. Moral memiliki kedudukan yang amat penting, karena manusia dalam hidupnya harus taat dan patuh pada norma-norma, aturan-aturan, adat istiadat, undang-undang, dan hukum yang ada dalam suatu masyarakat. Norma-norma, aturan-aturan, undang-undang, dan hukum, baik yang dibuat atas kesepakatan sekelompok manusia atau aturan yang berasal dari Tuhan.

Moralitas tidak dapat dipisahkan dalam kehidupan sehari-hari seseorang, moralitas selalu berkaitan dengan tindakan yang dilakukan seseorang, baik maupun buruk. Oleh karena itu, di dalam setiap film selalu disisipkan aspek moralitas, tidak kecuali film yang bertemakan tentang romantisme ataupun kehidupan seseorang. Moral pun dapat mempengaruhi status seseorang di dalam masyarakat, contoh: orang yang memiliki nilai yang baik biasanya orang tersebut disegani oleh masyarakat, selalu diterima oleh masyarakat karena moralnya baik, selalu membantu warga yang kesusahan, berbanding terbalik jika orang tersebut memiliki nilai moral yang buruk dalam masyarakatnya, otomatis orang tersebut selalu dijauhi oleh masyarakat, contoh: seorang preman akan selalu dimusuhi oleh masyarakat di lingkungan tempat dia tinggal.

Dalam hal ini penulis melakukan penelitian yang mengangkat tema yaitu film yang memiliki nilai moral dalam kehidupan umat manusia. Film tersebut berjudul Cinderella. Penulis merasa perlu menganalisis aspek moralitas di dalam film tersebut karena banyak aspek yang terkandung dalam film Cinderella ini. Dalam film ini penulis akan menganalisis unsur-unsur yang ada di dalam moralitas menurut Borba (2008), dibagi menjadi 7 unsur yaitu unsur empati, hati nurani, kontrol diri, rasa hormat, kebaikan hati, toleransi dan keadilan dalam aspek moralitas, keseluruhan aspek tersebut lebih sering terjadi di dalam kehidupan sehari-hari seseorang, oleh karena itu penulis sangat tertarik untuk menganalisis unsur tersebut dan mengkaitkannya dalam film Cinderella. 


\section{B. KAJIAN TEORI}

\section{Hakikat Moral}

Moralitas berasal dari bahasa Latin, moralitas adalah pembawaan karakter, dan tingkah laku yang sepantasnya berdasarkan situasi dan kondisi. Moral adalah sesuai dengan ide-ide yang umum diterima tentang tindakan manusia mana yang lebih baik dan wajar. Moral merupakan kaidah norma dan pranata yang mengatur perilaku individu dalam kehidupannya dengan kelompok sosial dan masyarakat. Moral merupakan standar baik-buruk yang ditentukan bagi individu sebagai anggota sosial. Moralitas merupakan aspek kepribadian yang diperlukan seseorang dalam kaitannya dengan kehidupan sosial secara harmonis, adil, dan seimbang.

Menurut Kenny (dalam Nurgiyantoro, 2005:320) mengatakan: "Moral merupakan makna yang terkandung dalam karya seni, yang disaratkan lewat cerita. Moral dapat dipandang sebagai tema dalam bentuk yang sederhana, tetapi tidak semua tema merupakan moral".

Berdasarkan kutipan di atas, moral adalah isi dari karya seni yang disarankan melalui cerita yang ada pada karya seni, moral dapat dipandang sebagai tema dari karya seni, tetapi tidak semua tema merupakan moral dari karya seni.

Menurut Suseno (2000:19) "Moral adalah tolak ukur yang menentukan betul salahnya sikap dan tindakan manusia dilihat dari segi baik-buruknya sebagai manusia dan bukan sebagai pelaku peran tertentu dan terbatas."Berdasarkan pernyataan di atas moral tidak dilihat dari pelaku peran yang sifatnya terbatas namun moral dilihat dari sikap manusia baik itu baik maupun buruk.

Menurut Borba (2008) dalam bukunya yang berjudul "Membangun Kecerdasan Moral", moral dibagi ke dalam tujuh jenis: (1). Empati, adalah kemampuan untuk merasakan keadaan untuk mengerti dan merupakan suatu subtitusi diri sendiri pada diri orang lain, (2). Hati nurani, adalah menentukan baik buruk hal ini merupakan kesadaran moral yang sudah timbul dan berkembang atau penerapan kesadaran moral tindakan etis yang tertentu dalam segala situasi, (3).Kontrol diri, adalah merupakan pengendalian pikiran dan tindakan agar dapat menahan dorongan dari luar sehingga dapat bertindak dengan benar, (4).Rasa hormat, adalah menghargai orang lain dengan berlaku baik dan sopan, 
(5).Kebaikan hati, adalah menunjukkan kepedulian terhadap kesejahteraan dan perasaan orang lain, (6).Toleransi, adalah menghormati martabat dan hak semua orang, meskipun keyakinan dan perilaku mereka berbeda dengan kita, (7).Keadilan, adalah yakni berpikir terbuka serta bertindak adil tidak memihak siapapun dan benar.

Berdasarkan kutipan di atas, moral terbentuk karena tujuh unsur tersebut, sehingga jika terdapat unsur tersebut dalam seseorang maka dikatakan orang tersebut memiliki moral yang baik dalam masyarakat.

Menurut keempat para ahli di atas disimpulkan bahwa moral adalah perbuatan, tingkah laku atau ucapan seseorang dalam berinteraksi dengan manusia yang terkait dalam nilai-nilai baik dan buruk dalam kehidupan bermasyarakat yang utuh serta dalam hal budaya dan agama.

\section{Hakikat Moralitas}

Manusia sebagai makhluk sosial tidak dapat hidup seorang diri. Dalam menjalani hidupnya ia berhubungan dengan manusia dengan manusia lainnya yang hidup di tengah masyarakat yang memiliki kebudayaan, norma, dan peraturan yang harus dipenuhi dan ditaati. Pada gilirannya keberadaan aturan-aturan atau norma-norma itu ditujukan untuk menciptakan suatu tatanan kehidupan yang seimbang, harmonis, dan memiliki nilai manfaat yang sangat dibutuhkan oleh masyarakat itu sendiri. Sudah barang tentu setiap aturan, norma, peraturan dan lain-lain didasarkan salah satunya oleh sistem nilai-nilai atau kaidah yang hakiki pada manusia yaitu moralitas.

Jika dihubungkan dengan film, aspek moralitas adalah hasil dari pengungkapan isi film tersebut, karena terkadang di dalam novel tidak selamanya mencerminkan hal-hal mencerminkan kebaikan selalu sesuai dengan moral.

Berbagai bentuk perbuatan diatas bisa jadi tidak akan sanggup bertahan, sebab terdapat jenis-jenis yang sebagaimana juga sangat distruktif bagi manusia. Orang membedakan antara pelanggaran terhadap konvensi sosial dan pelanggaran moral, maka rasa malu yang mungkin akan selalu dirasakanpun akan berbeda tarafnya. Kita meletakan moralitas di tempat yang penting dan khusus bukan karena hal tersebut telah dijadikan sistem nilai-nilai sosial itu lebih dikarenakan aturan tersebut memiliki nilai moral. 
Menurut paparan di atas, dapat disimpulkan bahwa moralitas adalah kualitas refleksi dari perbuatan manusia yang mewujudkan perbuatan itu benar atau salah, baik atau buruk terhadap nilai-nilai, aturan, etika, dan nilai-nilai kehidupan manusia di dalam sebuah masyarakat.

\section{Hakikat Karya Sastra}

Menurut Teuw (2013:20) "Kata sastra berasal dari bahasa Sansekerta dari akar kata sas-, dalam kata kerja turunan yang berarti mengarahkan, mengajar, memberikan petunjuk atau intruksi. Akhiran kata tra- biasanya menunjukkan alat, suasana". Maka dari sastra dapat berarti alat untuk mengajar, buku petunjuk, buku intruksi, dan pengajaran: misalnya silapastra, buku arsitektur, kesusteraan, buku petunjuk mengenai seni cerita. Awalan suberarti baik, indah sehingga susastra dapat dibandingkan dengan belles letter (tulisan yang halus). Maka dapat disimpulkan bahwa sastra adalah alat untuk mengajar yang mengarahkan atau memberikan petunjuk mengenai sebuah seni cerita.

Menurut Laelasari dan Nurlailah (2006:225): "Sastra adalah setiap bahasa berbentuk syair berisi imajinasi yang baik, ilustrasi yang indah, makna yang kuat dan hikmah yang sesuai yang berpengaruh terhadap pembinaan jiwa, kepekaan rasa dan kefasihan lisan. " Hasil karya sastra dibuat untuk mewakili perasaan atau pengalaman seorang pembuat karya sastra tersebut, sehingga dalam karya sastra bahasa yang digunakan cenderung bahasa yang memiliki suatu gambaran akan keindahan ataupun sebaliknya, memiliki makna baik secara tersirat maupun secara tersurat dan memiliki tujuan akan penciptaan karya sastra yang ada. Berdasarkan kutipan di atas, karya sastra dibuat untuk mewakili perasaan dan pengalaman penulis dengan menggunakan bahasa yang cenderung memiliki gambaran akan keindahan maupun sebaliknya.

Luxemburg (2001:12) yang diterjemahkan oleh Hartoko dalam "Pengantar Ilmu Sastra" mendefinisikan karya sastra sebagai pembuka batin manusia bagi pengalaman-pengalaman baru atau karya sastra mengajak manusia mengatur pengalaman tersebut dengan suatu cara baru.

Berdasarkan kutipan tersebut karya sastra adalah pembuka batin manusia untuk membuka pengalaman baru, karya sastra digunakan untuk menuliskan pengalaman-pengalaman yang telah dialami oleh manusia dan dapat dijadikan sebagai pembuka batin atau sebagai alat untuk membagi sejumlah pengalaman melalui karya sastra sebagai sarana untuk mengekspresikan pengalaman tersebut. 
Menurut para ahli di atas, penulis simpulkan bahwa karya sastra adalah penciptaan yang disampaikan kepada komunikatif tentang maksud penulis untuk tujuan estetika dalam kehidupan seseorang yang dianggap mengesankan.

\section{Hakikat Film}

Carrol (2008:1) dalam bukunya yang berjudul "The Philosophy of Motion Pictures “ mengatakan "Though the phylosophy of the motion picture-or, as I prefer to say, the moving image-began early in the twentieth century, perhaps arguably with the publication in 1916 of . Dari penjelasan ini dapat diuraikan bahwa istilah pertama kali yang digunakan untuk film atau movie yang selama ini dikenal bersumber dari kata movie image. Pada awalnya film dimasukkan kedalam kajian fotografi bukan film sebagai sebuah karya seni. Perkembangan film muncul pada awal abad k-20 tetapi banyak yang menyebutkan film muncul pada tahun 1916.

Jilnel (2005:8) dalam "An Introduction to Film Studies" menjelaskan bahwa film tidak bisa dilepaskan dari tiga bidang yaitu exhibition, distribution dan production.

"Exhibition is division of the film industry concentrating on the public screening film. Distribution is division concentrating on the marketing film, connecting the producer with the exhibitor by easing film from the former and renting them to the latter production is division on the marketing of film."

Berdasarkan kutipan di atas dapat dijelaskan bahwa film merupakan kajian yang sangat luas, yaitu berkaitan dengan bagaimana sebuah film diproduksi dalam konteks yang luas untuk kepentingan umum, kemudian berkaitan dengan bagaimana memasarkan hasil produksi film tersebut. Kemudian berbicara film berbicara juga tentang bagaimana film tersebut diproduksi. Penjelasan ini mengungkapkan bahwa perfilman yang sangat luas. Klarer (2005:53) menjelaskan:

"Film is idiosyncratic modes of presentation-such as camera angle, editing montage, slow and fast motion-often parallel features of literacy texts or can be explained within a textual framework. Although film has it own specific characteristics and terminology, it is possible to analyze film by drawing on the method of literacy critism, as film is closely related to the traditional approaches of textual studies." 
Film merupakan model presentasi dari sebuah karya sastra yang ditampilkan dalam bentuk kamera dimana terjadi proses editing, montase, yang menampilkan isi cerita dan cerita adalah bagian dari karya sastra yang berbentuk textual. Walaupun film memiliki karakteristik dan terminologi sendiri tetapi film selalu dianalisis melalui pendekatan sastra. Berdasarkan penjelasan di atas maka dapat dijelaskan bahwa film merupakan bagian dari karya sastra karena masih menggunakan cerita dari teks dalam penyampaiannya.

Script atau screenplay merupakan bagian dari pembuatan film berisi konsep cerita yang akan ditampilkan. Mills (2006:193) mengatakan "Writing a successful film screenplay come to seem like the blue-print of screenplay story itself, one of feature-fil proportions, in which the central character". Kutipan di atas menjelaskan bahwa film merupakan cerita yang bersumber dari skrip, dan skrip tersebut merupakan karya sastra teks. Di dalam skrip tersebut tergambar karakter tokoh yang akan berperan dalam suatu cerita.

Menurut para ahli diatas, penulis simpulkan bahwa film adalah karya seni yang berupa rangkaian gambar hidup yang diputar sehingga menghasilkan sebuah ilusi gambar bergerak yang disajikan sebagai bentuk hiburan dengan bentuk ekspresi, pemikiran, ide, konsep, perasaan dan suasana hati dari seorang manusia yang divisualisasikan dalam film.

\section{METODE PENELITIAN}

Jenis penelitian ini adalah deskriptif kualitatif. Metode pengumpulan data yang digunakan dalam penelitian ini adalah simak dan catat. Instrumen dalam penelitian ini adalah teori deiksis persona. Metode analisis data yang digunakan adalah metode padan dengan menggunakan teknik dasar PUP (Pilah Unsur Penentu).

\section{HASIL DAN PEMBAHASAN}

Berikut ini adalah uraian deskripsi temuan tujuh nilai moral yaitu: nilai moral empati, hati nurani, kontrol diri, rasa hormat, kebaikan hati, toleransi, dan keadilan yang terdapat pada film Cinderella. 


\section{Tabel 1 Tabel Nilai Moral dan Pembahasan}

\begin{tabular}{|c|c|c|c|}
\hline No & Nilai Moral & Definisi dan Uraian Dalam Narasi Film & Pembahasan \\
\hline 1 & Empati & $\begin{array}{l}\text { Empati adalah kemampuan untuk merasakan } \\
\text { keadaan untuk mengerti dan merupakan suatu } \\
\text { subtitusi diri sendiri pada diri orang lain. } \\
\text { Petani John: Ini tentang ayahmu, Nona. Dia sudah } \\
\text { tiada, sampai akhir hayatnya ia hanya } \\
\text { membicarakanmu dan ibumu } \\
\text { Ella: Terima kasih. Ini pasti sulit bagimu. }\end{array}$ & $\begin{array}{l}\text { Ella mengungkapkan } \\
\text { rasa empatinya kepada } \\
\text { ibu tirinya namun ibu } \\
\text { tirinya tidak } \\
\text { mengacuhkannya dan } \\
\text { tetap memesan hanya } \\
\text { tiga gaun untuk pesta } \\
\text { dansa. }\end{array}$ \\
\hline & & $\begin{array}{l}\text { Ella: Aku hanya gadis biasa bukan seorang putri. } \\
\text { Kadal: Dan aku hanya seekor kadal, bukan } \\
\text { pelayan. Nikmatlah selagi bisa }\end{array}$ & $\begin{array}{l}\text { Tuan kadal } \\
\text { mengutarakan rasa } \\
\text { empatinya kepada Ella } \\
\text { ketika mereka tiba di } \\
\text { istana. Tuan kadal } \\
\text { mengatakan agar Ella } \\
\text { memanfaatkan waktu } \\
\text { yang dia punya selagi } \\
\text { bisa }\end{array}$ \\
\hline 2 & Hati Nurani. & $\begin{array}{l}\text { Hati nurani adalah memberikan baik dan buruk, } \\
\text { hal ini merupakan kesadaran yang sudah timbul } \\
\text { dan berkembang atau penerapan kesadaran moral }\end{array}$ & $\begin{array}{l}\text { Ketika di hutan, Ella } \\
\text { mencurahkan keluh } \\
\text { kesah yang ada di }\end{array}$ \\
\hline
\end{tabular}


tindakan etis yang tertentu dalam segala situasi.

Ella menyampaikan keluh kesahnya kepada Kit

Ella: Ini tidak terlalu buruk. Pasti ada yang lebih buruk. Kita harus punya keberanian dan baik hati, bukan?

Kit: Ya.

Jika harus menikah, boleh aku memilih gadis desa yang baik dan jujur?

Tn. Phineus: Berapa wilayah yang bisa diberikan oleh "gadis desa yang baik dan jujur”? hatinya kepada Kit tentang perlakuan yang dia dapatkan dari ibu dan saudara tirinya.

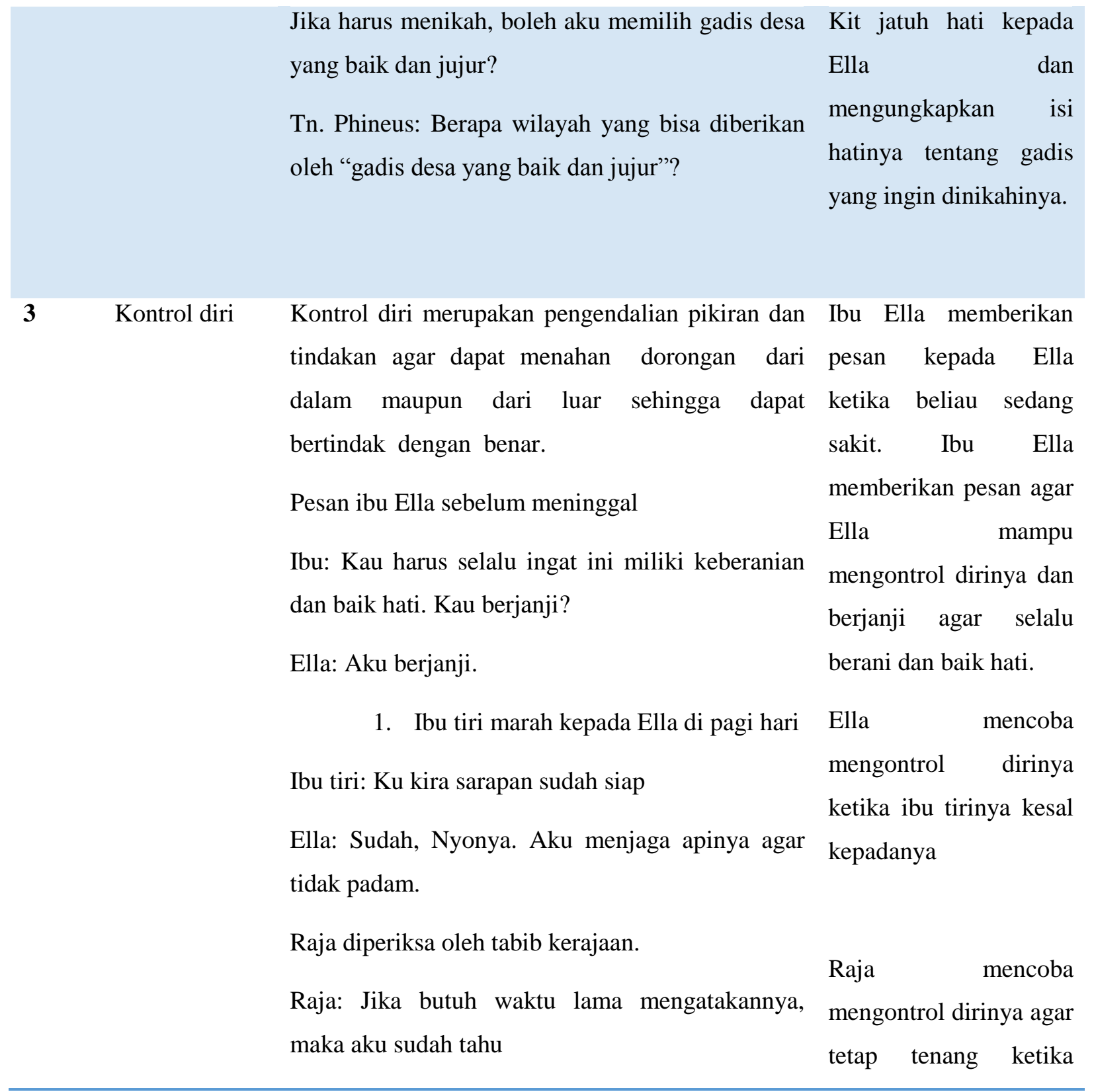




\section{Kit: Ayah}

Raja: Semua orang akan mati, Nak

Ibu tiri mengutarakan harapannya.

Ibu tiri: Salah satu dari kalian harus merebut hati pangeran. Maka kita bisa bebas dari hutanghutang yang menjerat ketika datang ke dusun ini.

Anastasia: Aku, seorang putri?

Ibu tiri merobek gaun yang dipakai Ella.

Ibu tiri: Gaun ini kuno sekali dan sudah rusak. Bahunya berjumbai. Gaunnya robek-robek.

Ella: Teganya kau.

Raja berusaha meyakinkan Kit tentang bagaimana perasaan Kit yang sebenarnya.

Kit: Ayah, ini untuk rakyat.

Raja: Ayah tahu kau mencintai rakyat, Kit. Tapi Ayah juga tahu kau sedang jatuh cinta.

Ibu tiri memecahkan sepatu kaca milik Ella.

Ella: Kenapa kau kejam sekali? Aku tak mengerti, ku coba bersikap baik kepadamu.

Ibu tiri: Kau? Baik kepadaku?

Ella akhirnya bertemu pangeran dan mencoba sepatu kaca.

Ella: Bahkan aku tak tahu apakah sepatu yang indah itu akan muat. Tapi jika muat apakah kau akan menerimaku apa adanya?

Kit: Tentu.

tabib kerajaan
mengetahui bahwa
kondisinya tidak baik

Setelah mengetahui bahwa ada pesta dansa di istana, ibu tiri Ella berharap agar salah satu putri nya dapat menjadi istri pangeran. Ibu tiri Ella berusaha mengontrol dirinya agar tetap tenang.

: Ella mencoba mengontrol dirinya dan menahan amarahnya karena ibu tiri merusak gaun milik ibu yang dipakai oleh Ella

Di pesta dansa, pangeran tampak mencari gadis yang ditemuinya di hutan. Namun raja mengetahui bahwa Kit menyukai gadis itu. Kit tampak sedang mengontrol dirinya dari rasa khawatir manakala gadis tersebut tidak 
datang ke pesta dansa.

: Ella berusaha

mengontrol dirinya dari

rasa bahagia yang

berlebihan karena dia

akan bertemu Kit dan

menikahinya apabila

sepatu kaca tersebut

muat di kakinya.

4 Rasa Hormat Rasa hormat adalah menghargai orang lain dengan berlaku baik dan sopan. Ini akan mendorong anak bersikap baik dan menghormati orang.

Ayah meminta izin Ella untuk menikah lagi.

Ella: Ayah khawatir mengatakannya kepadaku. Jangan khawatir. Jika itu membuat Ayah bahagia

Ella menunjukan rasa Ayah: Ya, kebahagiaan. Menurutmu Ayah boleh hormatnya kepada sang dapat satu kesempatan terakhir meski Ayah pikir hal semacam itu sudah berakhir?

ayah yang meminta izin untuk menikah kembali. Ayah tampak khawatir Ella berkeinginan ke pesta dansa dengan memakai gaun ibunya.

Ella akan menolaknya namun ternyata dengan

Ella: Kau tak perlu keluarkan uang. Ini gaun lama ibuku. Aku yang perbaiki.

rasa hormat Ella menyetujuinya.

Drisella: Cinderella di pesta dansa! Tak ada yang mau menikahi pembantu.

Ella menunjukan rasa

Ella ingin agar dia ke pesta dansa dengan memakai gaun ibunya.

hormatnya kepada ibunya dengan memperbaiki gaun Ella: Aku ingin memakai gaun ini saat pergi ke istana. Ini seperti mengajak ibu bersamaku.

milik ibunya dan gaun tersebut dipakainya ke 
Ibu peri: Aku mengerti.

Kit merasa terpukau dengan kecantikan Ella.

Kit: Aku salah mengiramu sebagai gadis desa yang baik dan jujur. Kini ku tahu kau tak ingin memesona prajurit biasa

Ella: Itu tak mungkin.

Ella berpapasan dengan Raja.

Ella: Putramu Kit adalah orang terbaik yang pernah ku kenal. Begitu baik dan berani. Ku harap kau tahu betapa dia menyayangimu.

Raja: Ya.

\section{Ella beradu argumen dengan ibu tiri}

Ella: Aku tak bisa melindungi Ayahku darimu tapi akan ku lindungi pangeran dan kerajaan apapun yang terjadi kepadaku.

Ibu tiri: Itu sebuah kesalahan.

Pembahasan: Ella menunjukan rasa hormatnya kepada pangeran dan kerajaan dan berusaha untuk melindunginya. Namun ibu tiri menyangkalnya. pesta dansa. Namun saudara tirinya bernama Drisella malah mengejeknya.

Awalnya ibu peri ingin mengganti gaun yang dipakai Ella namun Ella menunjukan rasa hormatnya kepada ibunya dengan memakai gaun milik ibunya ke pesta dansa di istana.

Ella secara tidak sengaja bertemu Raja dan memperlihatkan rasa hormatnya dan memberi tahu Raja bahwa pangeran adalah orang terbaik yang pernah dia temui.

Ella menunjukan rasa hormatnya kepada pangeran dan kerajaan dan berusaha untuk melindunginya. Namun ibu tiri menyangkalnya. 
Kebaikan hati adalah menunjukkan kepedulian terhadap kesejahteraan dan perasaan orang lain. Ini akan membantu anak mampu menunjukkan kepeduliannya terhadap kesejahteraan dan perasaan orang lain.

Ayah memberikan pesan sebelum pergi ke luar negeri.

Ella menunjukan

Ayah: Bersikap baiklah kepada ibu tirimu dan kebaikan hati yang saudari-saudari tirimu walau mungkin mereka sedikit sulit dimilikinya dengan berjanji akan bersikap baik kepada ibu tiri dan saudari-saudari tirinya.

Ella: Aku berjanji.

Ibu tiri memuji kecantikan kedua putrinya.

Ibu tiri: Ibu yakin di kerajaan ini tak ada yang Setelah Ella berjanji, Ayah pun merasa senang. lebih cantik dari anak-anak ibu.

Anastasia: Ya, ibu.

Ella bertemu ibu peri.

Ketika ibu tiri melihat putri-putrinya sudah Ibu peri: Kenapa kau menangis? siap pergi ke istana

Ella: Tidak apa-apa. dengan gaun yang sangat indah, ibu tiri Ibu peri: Tapi kebaikan membuatnya berarti. merasa yakin bahwa mereka akan membuat Pembahasan: Ibu tiri menunjukan kebaikan hatinya dengan menanyakan alasan Ella menangis. Dia mengetahui bahwa Ella adalah gadis yang baik dan penyabar.

pangeran kagum. Ibu tiri menujukan kebaikan hatinya dengan memuji Drisella

1. Ibu peri mengatakan kapan sihirnya dan Anastasia. akan sirna.

Ibu tiri menunjukan Ibu peri: Pada gema terakhir dari lonceng tengah kebaikan hatinya 
malam, mantranya akan sirna dan semua akan dengan menanyakan

kembali seperti semula.

Ella: Tengah malam? Itu lebih dari cukup.

Pangeran menunjukan taman rahasia kepada Ella.

Kit: Belum pernah ku perlihatkan tempat ini kepada siapa pun

Ella: Taman rahasia. alasan Ella menangis.

Dia mengetahui bahwa Ella adalah gadis yang baik dan penyabar.

Ella merasa kebaikan hati yang diberikan oleh ibu peri kepadanya lebih dari cukup. Ibu peri memberinya kesempatan untuk bertemu Kit walaupun sihir yang diberikan kepadanya akan sirna pada tengah malam.

\section{Toleransi Toleransi adalah menghormati martabat dan hak semua orang, meskipun keyakinan dan perilaku mereka berbeda dengan kita. \\ Ibu tiri berusaha menghibur Ella.}

Ibu tiri: Ella sayang, sudahlah jangan menangis.

Ella: Ya, Ibu tiri.

Ella mengizinkan agar saudari tirinya memakai kamarnya.

Ibu tiri: Mereka merasa kamar mereka sempit.

Ella: Kamarku terbesar setelah kamarmu dan Ayah. Mungkin mereka ingin berbagi.

Ella berusaha melindungi rusa yang sedang diburu.

Ella: Apa salahnya kepadamu sehingga kau
Setelah Ayah Ella berangkat, Ella merasa sedih dan menangis namun ibu tiri menunjukan sikap toleransinya dan berusaha menghibur Ella.

Ella menunjukan sikap toleransinya dengan mengizinkan agar 


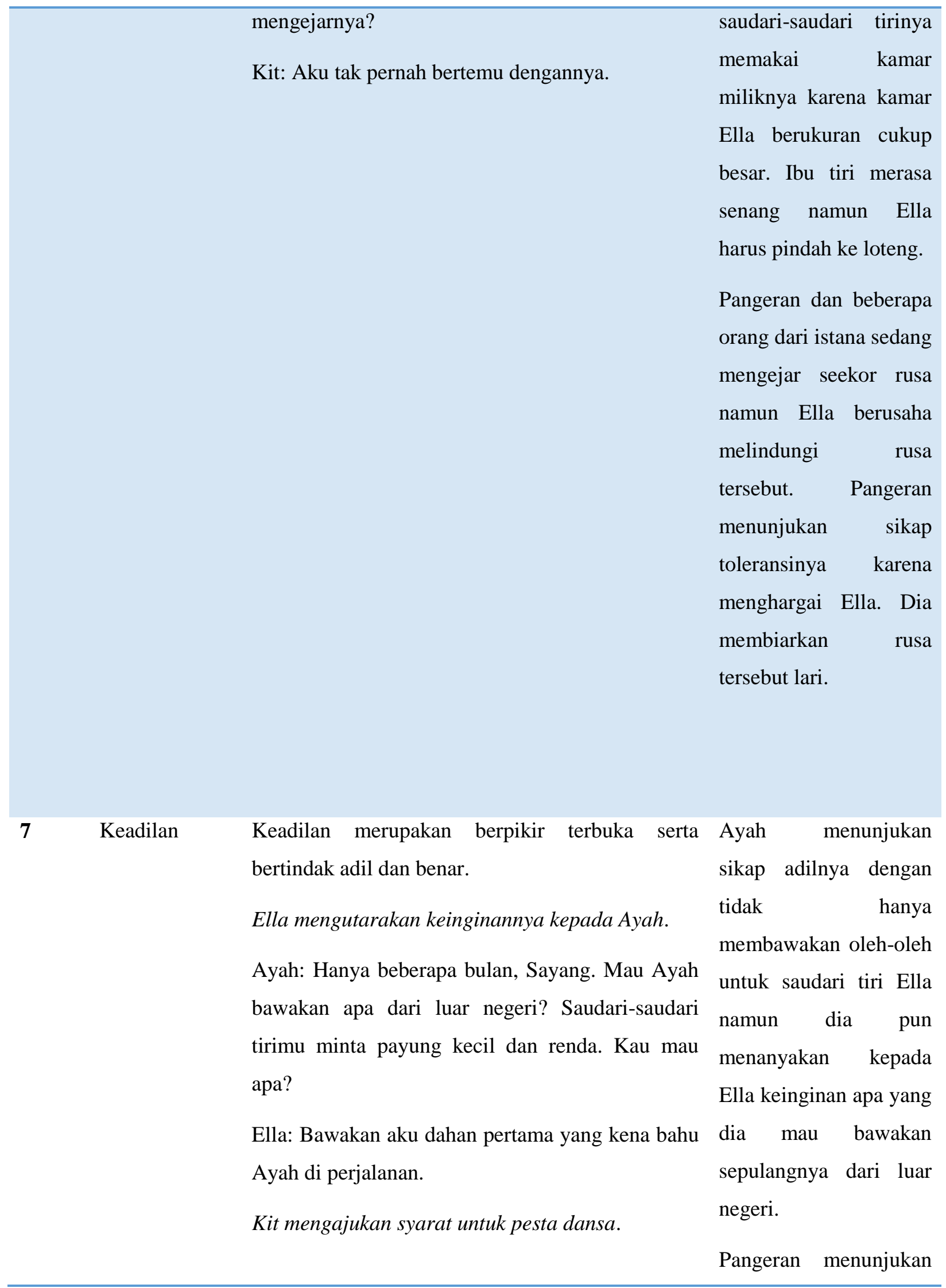


Raja: Ayah ingin agar kau dan kerajaan aman.

Kit: Baik, Ayah. Dengan satu syarat sebarkan undangan ke semua orang, bukan hanya bangsawan. Perang membuat kita semua berduka.

Ibu peri menanyakan benda yang dapat disihir menjadi kereta.

Ibu peri: Kita butuh sesuatu yang mirip kereta kuda. Aku lebih suka buah atau sayuran.

Ella: Kami punya labu.

Pangeran mengutarakan pendapatnya kepada Raja.

Kit: Yang kita butuhkan ada di sini. Kita hanya butuh keberanian dan kebaikan untuk melihatnya.

Raja: Kau sudah dewasa.

Rombongan kerajaan berusaha mencari pemilik sepatu kaca.

Kapten: Kita belum menemukan gadis itu. Aku mengecewakan raja kita.

Tn. Phineus: Ayolah, jangan putus asa. Ada satu rumah lagi. Kita harus periksa seluruh pelosok.

\section{Ella diminta mencoba sepatu kaca.}

Kapten: Kau diminta untuk menghadap Raja.

Ibu tiri: Ku larang kau melakukan ini.

Kapten: Dan ku larang kau untuk melarangnya! Siapa kau berani menghentikan utusan Raja?

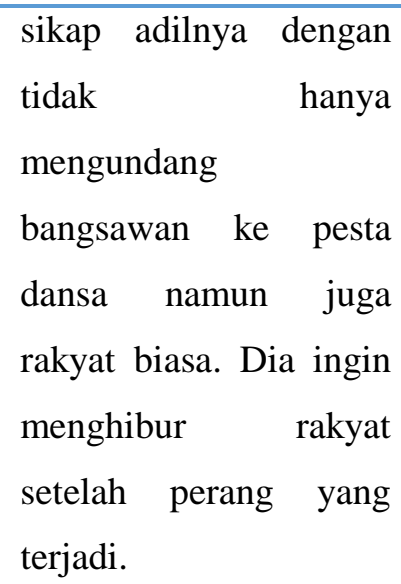

Ella tampak tidak percaya bahwa ibu peri itu memang ada sehingga ketika ibu peri ingin merubah sesuatu menjadi kereta Ella memberi tahu bahwa mereka menanam labu. Ibu peri menunjukan sikap adilnya dengan menyihir labu tersebut.

Kit mengatakan bahwa kerajaan tidak membutuhkan apa pun selain keberanian dan kebaikan hati. Dia menunjukan wibawa dan rasa adil nya sebagai penerus tahta kerajaan.

Adipati kerajaan, Tn. Phineus berusaha untuk 


\begin{tabular}{l}
\hline menepati janjinya \\
kepada raja untuk \\
bersikap adil dan \\
mencari gadis misterius \\
yang muat dengan \\
sepatukaca. \\
Kapten utusan Raja \\
menunjukan sikap \\
adilnya agar setiap \\
wanita di pelosok \\
negeri harus mencoba \\
sepatu kaca tersebut \\
termasuk Ella. Ella \\
akhirnya diperbolehkan \\
keluar kamar dan \\
bertemu Raja.
\end{tabular}

Menafsirkan sebuah pesan moral bukanlah hal yang mudah. Karena pesan moral dalam sebuah cerita yang terdapat dalam film tidak akan dikemukakan secara langsung, biasanya dikemukakan secara tersirat melalui adega, dialog dan pemeran film tersebut. Pesan moral yang hadir dalam sebuah cerita film dapat memberikan nilai positif dan pelajaran bagi kehidupan penontonnya. Maka peranan penontonlah yang dapat menilai dan memberi tanggapan atas film tersebut baik itu positif atau negatif, semua itu dapat dilihat dari pesan moral yang terdapat dalam film tersebut.

Maka nilai moral yang terdapat dalam film ini adalah keberanian dan kebaikan hati manusia dapat memberikan pengaruh positif bagi kehidupan. Pada film ini, tokoh utama yang bernama Ella telah berjanji kepada ibunya sebelum beliau meninggal agar selalu bersikap berani dan baik hati kepada siapa pun jua. Ketulusan tokoh utama ini memberikan dampak yang 
signifikan dalam perkembangan plot film ini. Walaupun orang tua Ella telah tiada, namun dia selalu memegang janjinya agar selalu bersikap berani dan baik hati. Itulah alasan mengapa pangeran jatuh hati kepadanya.

Selain itu, pesan moral yang disampaikan oleh film ini kepada penonton adalah bahwa kebaikan akan selalu menang melawan keburukan bagaimana pun keadaannya. Ella selalu berbuat baik walaupun diperlakukan secara kejam oleh ibu tiri dan saudari-saudari tirinya. Sebagai balasannya, Ella mendapat kesempatan untuk pergi ke pesta dansa dengan bantuan ibu peri. Ibu peri dalam film ini memang tidak ada di kehidupan nyata namun dalam film ini, ibu peri menjadi sosok yang membalas kebaikan dan keberanian tokoh utama, Ella. Dari hasil penelitian tersebut di dapatlah hasil dari nilai moral empati sebesar $9,09 \%$, hati nurani $6,06 \%$, kontrol diri $24,24 \%$, rasa hormat $18,18 \%$, kebaikan hati $15,15 \%$, toleransi $9,09 \%$, dan keadilan $18,18 \%$. Berikut diagram batang hasil penelitian ini:

\section{E. KESIMPULAN}

Berdasarkan pemaparan dan uraian pada bab sebelumnya maka dapat disimpulkan bahwa presentase tertinggi dalam menganalisa aspek moralitas berdasarkan teori Borba adalah kontrol diri dengan presentase $24,24 \%$, diikuti oleh rasa hormat dan keadilan sebesar $18,18 \%$, kemudian kebaikan hati 15,15\% setelah itu empati dan toleransi sebesar 9,09\% dan terakhir hati nurani sebesar 6,06\%. Berdasarkan pada kesimpulan yang telah diuraikan diatas, maka penulis ingin memberikan beberapa saran :

1. Menjadikan penelitian ini sebagai suatu alternatif kepada para pembaca agar lebih mengapresiasi karya sastra khususnya film.

2. Pembaca dapat mengambil pesan moral positif yang ada dalam tulisan ini, sehingga mendapatkan inspirasi atau bahkan motivasi yang berguna bagi kehidupan.

3. Bagi mahasiswa yang akan meneliti film yang sama, diharapkan dapat menganalisis unsurunsur lain seperti tokoh dan penokohan, alur, atau aspek psikologi dalam film ini. 


\section{F. SARAN}

Penelitian tentang aspek moralitas pada siswa perlu mendpat perhatian, karena moral menjadi aspek penting dalam kehidupan manusia kelak. Siswa mampu mengakomodir semua aspek moral dalam kehidupan. Pembeajra melalui film juga dapat dikembangkan lebih lanjut, demi pencapaian pendidikan karakter siswa.

\section{DAFTAR PUSTAKA}

Ati, A. P., \& Widiyarto, S. (2019). Pembinaan Karakter Melalui Kegiatan Membaca Kritis Pada Siswa SMP Kota Bekasi. MATAPPA: Jurnal Pengabdian Kepada Masyarakat, 2(1), 3942.

Borba, M. (2008). Membangun Kecerdasan Moral, Tujuh Kebajikan Utama agar Anak

Bermoral Tinggi. Jakarta: PT. Gramedia Pustaka Utama.

Carrol, N. (2008). "Theorizing of Moving Image”. New York: Cambrigde University Press.

Jilnel. (2005). “An Introduction to Film Studies. ”Ohio: Routledge.

Klarer, M. (2013).“An Introduction to Literary Studies. "Routledge.

Laelasari dan Nurlailah. (2006). Kamus Istilah Sastra. Bandung: Nuansa Aulia.

Magnis, Suseno, F. (2000). Etika Dasar :Masalah-Masalah Pokok Filsafat Moral. Yogyakarta: Kanisius.

Mills, Paul. (2006). The Routledge Creative Writing Coursebook. New York: Routledge Taylor and Francis Group

Moloeng, L. J. (2002). Metode Penelitian Kualitatif. Bandung: Remaja Rosda.

Nurgiyantoro, B. (2005). Sastra Anak, Pengantar Pemahaman Dunia Anak, Yogyakarta: Gadjah Mada University Press.

Oxford Learner's Pocket Dictionary. (2011). United Kingdom: Oxford University Press.

Semi, M.A. (2008). Anatomi Sastra. Bandung: Angkasa Raya.

Teuw, A. (2013). Sastra Dan Ilmu Sastra. Jakarta: Pustaka Jaya.

Wehmier, S. (2005). Oxford Advaneed Learner's Dictionary. New York: Oxford University Press. 